\title{
THE EFFECT OF WORK DISCIPLINE, WORK ETHIC AND WORK ENVIRONMENT ON WORK MOTIVATION AND ITS IMPACT ON EMPLOYEE PERFORMANCE OF ACEH EDUCATION OFFICE PROVINCE OF ACEH, INDONESIA
}

\author{
Mukhlis, Muhammad Adam, Muslim A. Djalil* \\ Magister Management Program, Faculty of Economy and Business, \\ Universitas Syiah Kuala, Banda Aceh, Indonesia \\ *Corresponding Author
}

DOI: 10.46609/IJSSER.2020.v05i03.007 URL: https://doi.org/10.46609/IJSSER.2020.v05i03.007

\begin{abstract}
Aceh Education Office is working to improve the work skills and technical skills of employees in the direction of professionalism in the field of service. The phenomenon of the Aceh Education Office shows that the performance of their staff still needs to be improved. So it is necessary to study to see the factors that affect the performance of Aceh Education Office staff. The purpose of this study is to determine the effect of work discipline, work ethic, and work environment on work motivation and its impact on employee performance of Aceh Education Office. Using the Slovin formula, the sample size in this study was 206 employees, distributed proportionally to all employees by position. Questionnaires were used to collect data. The data was then analyzed using SEM with the help of AMOS 22.0 program. The results show that work discipline, work ethic, and work environment have a significant effect on work motivation and employee performance of Aceh Education Office. Other results show that work discipline, work ethic, and work environment have a significant effect on employee performance through work motivation.
\end{abstract}

Keywords: Work discipline, Work ethic, Work environment, Work motivation, Employee performance

\section{INTRODUCTION}

Based on Law Number 2, Year 2003 on National Education System, education is intended for all Indonesian people and one of the objectives is to increase the intelligence and welfare of the 


\section{International Journal of Social Science and Economic Research}

ISSN: $2455-8834$

Volume: 05, Issue: 03 "March 2020"

population maximally. Aceh Education Office also assumes the same mandate in improving the quality of education for the people of Aceh. In order to achieve its vision, Aceh Education Office is fully aware that the role of Human Resources as the subject and source of value creation of the organization is committed to continuously develop the potential of human resources consistently and sustainably.

Achievement targets IKU Aceh Education Office has not reached 100\% in 2016. So it is still necessary to work harder, focused, and focused efforts with consideration of a number of analyzes that affect. Meanwhile, 16 other target performance indicators have 1\% to $97,81 \%$ achievement. The phenomenon of Aceh Education Office shows that the performance of Aceh Education Office staff still needs to be improved. So it is necessary to study to see the factors that affect the performance of Aceh Education Office staff.

Based on preliminary research conducted by researchers, the performance of employees of Aceh Education Office one of them influenced the motivation of work. At the Aceh Education Office, employee motivation to provide good performance is still lacking. Work motivation is an influential condition for generating, directing, and maintaining work-related behaviors.

Performance and work motivation of employees at the Aceh Education Office one of which is influenced by the discipline of work from employees. At the Aceh Education Office, discipline is not only about the timely attendance of the workplace but more accurately defined as an attitude, behavior, and deed in accordance with the rules of the organization, whether written or not.

In addition, the performance and motivation of the employees in the Aceh Education Office is also influenced by the work ethic of its employees. Every organization that always wants to go forward will involve employees to improve the quality of their work, including every organization must have a good work ethic. The phenomenon that occurred in the Aceh Education Office is the work ethic of employees who are still lacking.

By 2016, no employee will arrive on time. As many as $90 \%$ of the total employee is also faster home compared to the hours of work home should be. In addition, as many as $50 \%$ of employees also perform truant work or not present work without explanation.

Another factor that affects the performance and motivation of employee work on the Aceh Education Office is the work environment. The work environment is very influential on the implementation of regulations within the Aceh Education Office. In organizations such as Aceh Education Office can be sure to strive to pay attention to the work environment of its employees to support its performance. Therefore, good cooperation between employees and superiors is needed. 
From all backgrounds of this study, the phenomenon that occurred in the Office of Education of Aceh is still low performance of employees caused by low employee motivation. Based on the above background, the purpose of this study is to analyze the "Effect of Work Discipline, Work Ethic and Work Environment To Work Motivation and Its Impact on Employee Performance of Aceh Education Office".

This study is aimed at investigating the influence of work discipline, work ethic, and work environment on employee performance of Aceh Education Office either directly or indirectly through work motivation.

\section{LITERATURE REVIEW}

\section{Performance}

Performance is the result of work that has a strong relationship with the strategic goals of the organization, consumer satisfaction and contribute to the economy (Armstrong and Baron, 2011).

Performance evaluation by Kreitner and Kinichi (2011) is an evaluative opinion of a person's traits, behaviors, or achievements as a basis for decision and personnel development plans. And Performance Evaluation is a process of evaluating worker performance, sharing information with them, and looking for ways to improve its performance. Performance evaluation is the process by which the organization evaluates performance achievement. When properly implemented, the employee, the principal supervisor (supervisor), the HR department and the organization ultimately benefit.

\section{Work Motivation}

Work motivation can be viewed as a feature that exists in the prospective workforce when accepted to work in a company or organization. This is very supportive because the definition of work motivation is an influential condition to generate, direct, and maintain behavior related to the work environment.

In a journal written by Irum Shahzadi et al. (2014) explained that there is a significant and positive relationship between work motivation and employee performance. Work motivation can provide energy that drives all the potential that exists, creates a high desire and noble, and improve togetherness.

\section{Work Discipline}

According to Rivai (2011) that work discipline is a tool used by managers to communicate with 
International Journal of Social Science and Economic Research

ISSN: $2455-8834$

Volume: 05, Issue: 03 "March 2020"

employees so that they are willing to change a behavior as well as an effort to raise awareness and willingness of a person in fulfilling all company regulations.

Without good discipline, it is difficult for the organization to achieve optimal results. Discipline is the main factor that is needed as a tool warning against employees who do not want to change the nature and behavior. So an employee is said to have good discipline if the employee has a sense of responsibility towards the task assigned to him.

\section{Work Ethic}

According to Sinamo (2011) ethos is defined as a belief that serves as a behavioral guide for a person, group, or institution. Thus, the work ethic can be interpreted as a doctrine of work believed by a person or group of people as good and true that manifest in characteristic of their work behavior. The work ethic is a set of positive behaviors rooted in fundamental beliefs accompanied by total commitment to an integral work paradigm.

Harsono and Santoso (2016) who expressed work ethic as a work spirit based on certain values or norms. work ethic is a cultural norm that supports a person to do and be responsible for his work based on the belief that the work has intrinsic value.

\section{Work Environment}

Work environment according to Sukanto and Indriyo (2012) is everything that is around the workers and can affect in the work includes lighting arrangements, noise control, workplace hygiene settings and workplace security settings.

According to Basuki and Susilowati (2015), work environment is anything that is in the environment that can affect either directly or indirectly a person or group of people in carrying out its activities. According to Nitisemito (2016) the work environment is everything that is around employees and can affect in carrying out the tasks assigned to him for example in the presence of air conditioner (AC), adequate lighting and so forth.

\section{Hypothesis}

Based in the literature review discussed previously, a hypothesis can be used in this study as the followings:

H1: Work discipline, work ethic, work environment, work motivation and employee performance of Aceh Education Office are good.

$\mathrm{H} 2$ : Work discipline influences significantly towards employee work motivation of Aceh 
Education Office.

H3 : Work ethic influences significantly towards employee work motivation of Aceh Education Office.

H4 : Work environment influences significantly towards employee work motivation of Aceh Education Office.

H5 : Work discipline influences significantly towards employee performance of Aceh Education Office.

H6 : Work ethic influences significantly towards employee performance of Aceh Education Office.

H7 : Work environment influences significantly towards employee performance of Aceh Education Office.

H8 : Work motivation influences significantly towards employee performance of Aceh Education Office.

H9: Work discipline influences significantly towards employee performance of Aceh Education Office through work motivation.

H10 : Work ethic influences significantly towards employee performance of Aceh Education Office through work motivation.

H11: Work environment influences significantly towards employee performance of Aceh Education Office through work motivation.

\section{RESEARCH METHODS}

\section{Location of the study}

Location of this study is Aceh Education Office. The object of this research is employee of Aceh Education Office. This research will present about how the effect of work motivation on employee performance of Aceh Dinas Education.

\section{Sampling}

There are a total of 421 employees at Aceh Education Office. Since all population has been known, Slovin formula can be used in determining sampling number with error percentage of 5\% or e value as much as =0,05 (Sekaran, 2010). The formula is described as follows;

$n=N /\left(1+N e^{2}\right)$

$n=421 /\left(1+421 \times 0,05^{2}\right)$

$n=421 / 2,0525=206$ sample

Notes: 
n : number of sample

$\mathrm{N} \quad$ : number of population

e : percentage of inaccuracy due to sampling error that can be tolerated, as much as 0,05

Based on the calculation above, 206 samples were distributed proportionally to 5 positions in the Aceh Education Office.

\section{Data Analysis Method}

The Structural Equation Modeling (SEM) was used to analyze data. This model is derived from statistic software packet of AMOS 22.0 in the hypothesis model and analysis.

\section{FINDINGS AND DISCUSSIONS}

\section{Descriptive Analysis}

The following will explain the descriptive anagrams of each variable.

Table 1: Descriptive Analysis Result

\begin{tabular}{|l|c|}
\hline Indicator & Mean \\
\hline Work Discipline & 4,17 \\
\hline Work Ethic & 4,56 \\
\hline Work Environment & 4,56 \\
\hline Work Motivation & 4,19 \\
\hline Employee Performance & 4,54 \\
\hline \multicolumn{2}{|c|}{ Source: Primary data, 2017 (processed) }
\end{tabular}

a. Work Discipline (X1)

Work discipline have an average value of respondents answer 4,17. This shows that the work discipline of Aceh Education Office employee is good.

b. Work Ethic (X2)

Work ethic have an average value of respondents answer 4,56. This shows that the work ethic of Aceh Education Office employee is very good.

c. Work Environment (X3)

Work environment have an average value of respondents answer 4,56. This shows that the work environment of Aceh Education Office employee is very good.

d. Work Motivation (Y) 
Work motivation have an average value of respondents answer 4,19. This shows that the work motivation of Aceh Education Office employee is good.

e. Employee Performance $(Z)$

Employee performance have an average value of respondents answer 4,54. This shows that the employee performance of Aceh Education Office employee is very good.

\section{Hypothesis Testing}

After a structural model can be considered fit, the next process is to see if there is a significant influence between variables. Hypothesis testing is done by looking at the estimation of research models.

Here is a table of estimation results of the research model:

Table 2: Result of Model Estimation

Regression Weights: (Group number l - Default model)

\begin{tabular}{|c|c|c|c|c|}
\hline & Estimate S.E. & C.R. & $\mathrm{P}$ & Label \\
\hline Motivasi_Kerja <--- Disiplin_Kerja & $, 529,106$ & 4,965 & & par_4 \\
\hline Motivasi_Kerja <--- Etos_Kerja & 235 & 3,404 & *** & par_5 \\
\hline Motivasi_Kerja <--- Lingkungan_Kerja & ,049 & 2,060 &, 039 & par_8 \\
\hline Kinerja $\quad<--$ Etos_Kerja & $, 051 \quad, 129$ & 2,398 & $* * *$ & par_6 \\
\hline <-- Disiplin_Kerja & 113 & 3,572 & $* * *$ & par_7 \\
\hline <-- Lingkungan_Kerja & 104 & 2,143 & $* * *$ & par_9 \\
\hline$<--$ Motivasi Kerja &, 575 & 2,231 &, 026 & par 30 \\
\hline
\end{tabular}

Based on the results of the above estimation, it can be concluded the answer hypothesis $\mathrm{H} 2$ - $\mathrm{H} 8$ is as follows:

1. $\mathrm{H} 2 \rightarrow$ Work discipline influences significantly towards employee work motivation of Aceh Education Office. It is shown by the probability value of less than $0,05(* * *<0,05)$ and the $\mathrm{CR}$ value of 4,965 (CR >1,96). The value of positive estimation is 0,529 , which means it has a positive influence. In other words, if work discipline improves, work motivation will improve.

2. H3 $\rightarrow$ Work ethic influences significantly towards employee work motivation of Aceh Education Office. It is shown by the probability value of less than $0,05(* * *<0,05)$ and the $\mathrm{CR}$ value of 3,404 (CR >1,96). The value of positive estimation is 0,235 , which means it has a positive influence. In other words, if work ethic improves, work motivation will improve. 


\section{International Journal of Social Science and Economic Research}

Volume: 05, Issue: 03 "March 2020"

3. H4 $\rightarrow$ Work environment influences significantly towards employee work motivation of Aceh Education Office. It is shown by the probability value of less than 0,05 is 0,039 and the $\mathrm{CR}$ value of 2,060 ( $\mathrm{CR}>1,96)$. The value of positive estimation is 0,101 , which means it has a positive influence. In other words, if work environment improves, work motivation will improve.

4. H5 $\rightarrow$ Work discipline influences significantly towards employee performance of Aceh Education Office. It is shown by the probability value of less than $0,05(* * *<0,05)$ and the $\mathrm{CR}$ value of 3,572 (CR >1,96). The value of positive estimation is 0,113 , which means it has a positive influence. In other words, if work discipline improves, employee performance will improve.

5. H6 $\rightarrow$ Work ethic influences significantly towards employee performance of Aceh Education Office. It is shown by the probability value of less than $0,05(* * *<0,05)$ and the $\mathrm{CR}$ value of 2,398 ( $\mathrm{CR}>1,96)$. The value of positive estimation is 0,051 , which means it has a positive influence. In other words, if work ethic improves, employee performance will improve.

6. $\mathrm{H} 7 \rightarrow$ Work environment influences significantly towards employee performance of Aceh Education Office. It is shown by the probability value of less than $0,05(* * *<0,05)$ and the $\mathrm{CR}$ value of 2,143 (CR >1,96). The value of positive estimation is 0,104 , which means it has a positive influence. In other words, if work environment improves, employee performance will improve.

7. $\mathrm{H} 8 \rightarrow$ Work motivation influences significantly towards employee performance of Aceh Education Office. It is shown by the probability value of less than 0,05 is 0,026 and the CR value of 2, 2,231 (CR >1,96). The value of positive estimation is 0,575 , which means it has a positive influence. In other words, if work motivation improves, employee performance will improve.

To know the contribution of exogenous variable to endogenous variable and intervening variable can be seen from the adjusted $\mathrm{R}$ square. The coefficient of determination (R2) essentially measures how far the model's ability to explain endogenous variations.

It can be seen that the variable of work motivation influenced by work discipline variable, work ethic and work environment. The value of $\mathrm{R}$ square variable of work motivation is 0,819 which mean big contribution of variable of work discipline, work ethic and work environment to work motivation is equal to $81,9 \%$, while the rest influenced by other factor outside of that variable.

Employee performance variable is influenced by work motivation variable, work discipline, work ethic and work environment. $\mathrm{R}$ value of $\mathrm{R}$ square variable of employee performance is 0,821 which mean big contribution of work motivation variable, work discipline, work ethic and 
work environment to employee performance is equal to $82,1 \%$, while the rest influenced by other factors outside of variable.

The result of Path Analysis coefficient result can be seen on the output of Standardized Direct Effects, Standardized Indirect Effects, and Standardized Total Effects.

$1^{\text {st }}$ Equation of Path Analysis:

$$
\begin{aligned}
\mathbf{Y} & =\boldsymbol{\rho} \mathbf{x} \mathbf{1 y} \cdot \mathbf{X} \mathbf{1}+\boldsymbol{\rho} \mathbf{x} \mathbf{2 y} \cdot \mathbf{X} \mathbf{2}+\boldsymbol{\rho} \mathbf{x} \mathbf{3 y} \cdot \mathbf{X} 3+\boldsymbol{\varepsilon} \mathbf{1} \\
& =0,510 \mathrm{X} 1+0,304 \mathrm{X} 2+0,155 \mathrm{X} 3
\end{aligned}
$$

$2^{\text {nd }}$ Equation of Path Analysis:

$$
\begin{aligned}
\mathbf{Z} & =\rho \mathbf{x} 1 \mathrm{z} \cdot \mathbf{X} 1+\rho \mathbf{x} \mathbf{2 z \cdot X 2}+\boldsymbol{\rho} \mathbf{x} 3 \mathbf{z} \cdot \mathbf{X} 3+\boldsymbol{\rho} \mathbf{y z} \cdot \mathbf{Y}+\mathbf{\varepsilon} 2 \\
& =0,265 \mathrm{X} 1+0,240 \mathrm{X} 2+0,278 \mathrm{X} 3+0,287 \mathrm{Y}
\end{aligned}
$$

Notes:

$\mathrm{X} 1=$ work discipline

$\mathrm{X} 2$ = work ethic

$\mathrm{X} 3$ = work environment

$\mathrm{Y}=$ work motivation

$\mathrm{Z}=$ employee performance

$\varepsilon=$ eror (value 0 )

Based on the path analysis in prior, some conclusions can be drawn as the followings:

1. H9 : Work discipline influences significantly towards employee performance of Aceh Education Office through work motivation. Regression coefficient direct influence of work discipline on employee performance equal to 0,265 , regression coefficient indirect influence of work discipline to employee performance through work motivation equal to 0,059 , and total influence equal to 0,324 . With this it can be seen that the indirect influence of work discipline on employee performance through work motivation is smaller than the direct effect of work discipline on employee performance.

2. H10 : Work ethic influences significantly towards employee performance of Aceh Education Office through work motivation. Regression coefficient direct influence of work ethic to employee performance equal to 0,240 , regression coefficient indirect effect of work ethic to employee performance through work motivation equal to 0,124 , and total influence 
International Journal of Social Science and Economic Research

ISSN: $2455-8834$

Volume: 05, Issue: 03 "March 2020"

0,364 . With this it can be seen that the indirect influence of work ethic on employee performance through work motivation is smaller than the direct influence of work ethic on employee performance.

3. H11 : Work environment influences significantly towards employee performance of Aceh Education Office through work motivation. Regression coefficient of direct influence of work environment to employee performance equal to 0,278 , regression coefficient indirect influence of work environment to employee performance through work motivation equal to 0,068 , and total influence equal to 0,346 . With this it can be seen that the indirect effect of work environment on employee performance through work motivation is smaller than the direct influence of work environment on employee performance.

To know whether the indirect influence between variables is significant or not, then tested Sobel. The sobel test is used to determine the indirect effect of the mediation variable. To get the value of Sobel then used Calculator Sobel test application.

- Indirect effect of work discipline on employee performance through work motivation is significant because of the significance value of $0.023<0.05$. So that work motivation variable mediate influence of work discipline to employee performance.

- Indirect effect of work ethic on employee performance through work motivation is significant because of the significance value of $0.014<0.05$. So that work motivation variable mediate the influence of work ethic on employee performance.

- The indirect effect of work environment on employee performance through work motivation is significant because the significance value is $0.019<0.05$. So that work motivation variable mediate the influence of work environment on employee performance.

\section{CONCLUSIONS AND SUGGESTIONS}

\section{Conclusions}

1. Work discipline, work ethic, work environment and employee performance of Aceh Education Office are good.

2. Work discipline influences significantly toward employees' work motivation.

3. Work ethic influences significantly towards employees' work motivation.

4. Work environment influences significantly towards employees' work motivation.

5. Work discipline influences significantly toward employees performance.

6. Work ethic influences significantly on employees performance.

7. Work environment influences significantly on employee performance.

8. Work motivation influences significantly on employee performance . 
International Journal of Social Science and Economic Research

ISSN: $2455-8834$

Volume: 05, Issue: 03 "March 2020"

9. Work discipline influences significantly toward employee performance

10. Work ethic influences significantly towards employees performance of Aceh Education Office through work motivation. Thus, the variable of work motivation mediates the influence of work ethic to employee performance.

11. Work environment influences significantly toward employees performance of Aceh Education Office through work motivation. Thus, the variable of work motivation mediates the influence of work environment to employee performance.

\section{Recommendations}

1. To improve work discipline, supervision is required that leads employees to perform the job properly and in accordance with the established. Leaders in the Aceh Education Office should improve continuous work supervision and work discipline in the office area.

2. To improve work ethic, it requires high work discipline, both employees and leaders. Work ethic is able to encourage employee motivation to work well so as to create performance of employees of Aceh Provincial Education Office also become better. High work ethic both employees and leaders is one important factor that needs to be improved to improve performance, both employee performance and service performance.

3. To improve a good working environment, all employees should respect each other. A good working environment can create employee motivation to work properly so that it is expected to improve the performance of Aceh Education Office employee.

4. To improve work motivation, Aceh Education Office should improve relationships between employees and leaders. Establishing a good relationship should get more attention from the leadership of the Aceh Education Office because it can affect work motivation and employee performance.

5. To improve employee performance, an indicator that employees use existing resources effectively to complete the work should be improved. Employees who perform well by utilizing all available resources can result in maximum work that will improve the performance of the Aceh Provincial Education Office.

\section{REFERENCES}

Abdurrahmat Fathoni. 2010. Manajemen Sumber Daya Manusia. Bandung : Rineka Cipta.

Amstrong, Michael and Baron. 2011. Performance Management. London Institute of personnel and Development.

Baron \& Byrne. 2014. Social Psychology : Understanding Human Interaction (6th edition). 
International Journal of Social Science and Economic Research

ISSN: $2455-8834$

Volume: 05, Issue: 03 "March 2020"

USA: Needham Heights Allyn \& Bacon Inc

Budihardjo, M. 2014.Panduan Praktis Menyusun SOP, Cetakan Pertama, Raih Asa Sukses, Jakarta.

David A. 2013. Exploring charismatic leadership in the public sector: Measurement and consequences. Public Administration Review; ProQuest Research Library, Mar/Apr 2003; 63, 2. p. 229-242.

Davis, Keith dan Newstron, Jhon W. 2011. Perilaku dalam Organisasi. Jilid Kedua. Edisi Ketujuh. Jakarta: Erlangga.

Farida Saleem. 2014. Impact of Corporate Ethical Values on Employees' Behaviour: Mediating Role of Organizational Commitment. Pakistan Journal of Psychological Research, 2014, Vol. 29, No. 1, 245-263

Gibson et al., 2011. Organisasi (Terjemahan). Edisi kelima. Jakarta : Erlangga

Gitahi Njenga Samson, et all. 2015. Effect of Workplace Environment on the Performance of Commercial Banks Employees in Nakuru Town. International Journal of Business and Management ISSN 1833-3850 (Print) ISSN 1833-8119 (Online) Copyright () Canadian Center of Science and Education

Ilham Thaief, et all. 2015. Effect of Training, Compensation and Work Discipline against Employee Job Performance. Review of European Studies; Vol. 7, No. 11; 2015. ISSN 1918-7173 E-ISSN 1918-7181. Published by Canadian Center of Science and Education

Kirk L. Rogga. 2011. Human Resource Management. Prentice Hall, New Jersey.

Kopelman, R. E. 2012. Managing Productivity in Organizations: A Practical, People-Oriented Perspective, Mc Graw-Hill Book Company, New York.

Kotler, Philip. 2012. Marketing Management 13. New Jersey. Pearson Prentice Hall, Inc.

Kreitner, Robert. \& Kinicki, Angelo. 2011. Perilaku Organisasi (Organization Behavior) diterjemahkan oleh: Erly Suandy. Edisi 5. Jakarta: Salemba Empat.

Lenvine, Charles H. B. Guy Peters dan Frank J. Thompson. 2016. Public Administration Chelenge, Choices, Consequence. Illinois. Scott Foreman Little. New York: Brown Higher Education. 


\section{International Journal of Social Science and Economic Research}

ISSN: $2455-8834$

Volume: 05, Issue: 03 "March 2020"

Luthans, Fred. 2016. Organizational Behavior Eleventh Edition. The McGrawHill Companies, Inc.

Mangkunegara. 2011. Manajemen Sumber Daya Manusia, Cetakan Ke Tujuh. Bandung: PT. Remaja Rosdakarya.

Mathis, Robert L dan Jhon H. Jackson. 2011. Manajemen Sumber Daya Manusia, Buku I, Pener ernah Jimmy Sadeli dan Bayu. Prawira Hie. Jakarta: Salemba Empat.

Maxwell, John, C. 2012. Mengembangkan Kepemimpinan di dalam Diri Anda. Penerjemah: Lyndon Saputra. Jakarta: Penerbit Binarupa Aksara.

Moekijat. 2015. Manajemen Sumber Daya Manusia. Bandung: Pionir Jaya.

Nicholas Odoyo Simba, et all. 2016. Impact of Discipline on Academic Performance ofPupils in Public Primary Schools in Muhoroni Sub-County, Kenya. Journal of Education and Practice www.iiste.org ISSN 2222-1735 (Paper) ISSN 2222-288X (Online) Vol.7, No.6, 2016

Nispiansyah. 2012. Etos Kerja PNS. Pusat Pengembangan Tenaga Kependidikan, Jakarta.

Nur Zainie Abd Hamid. 2015. The Relationship Between Workplace Environment and Job Performance in Selected Government Offices in Shah Alam, Selangor. www.irmbrjournal.com September 2015 International Review of Management and Business Research Vol. 4 Issue.3

Prawirosentono, Suyadi. 2013. Manajemen Sumber Daya Manusia: Kebijakan Kinerja Karyawan, Kiat membangun Organisasi Kompetitif Menjelang Perdagangan Bebas Dunia. BPFE, Yogyakarta.

Rivai. 2011. Penilaian Prestasi Kerja Teori dan Praktek. Jakarta. PT. Ganudra Pustaka Utama.

Robbins, Sthepen P. 2012. Perilaku Organisasi, Edisi Bahasa Indonesia, Jilid II. Jakarta: PT. Indeks, Terjemahan Tim Indeks.

Sailendra, Annie. 2015. Langkah-Langkah Praktis Membuat SOP, Cetakan Pertama, Trans Idea Publishing, Yogyakarta.

Saydam. 2015. Manajemen Sumber Daya Manusia, Suatu Pendekatan Mikro. Jakarta: Djambaran. 
International Journal of Social Science and Economic Research

ISSN: 2455-8834

Volume: 05, Issue: 03 "March 2020"

Sekaran, Uma. 2012. Research Methods for Business. Southern Illionis, Universitas Carbondale, USA.

Shahrul Nizam bin Salahudin, et all. 2016. The Relationship between Work Ethics and Job Performance. BE-ci 2016 : 3rd International Conference on Business and Economics, 21 - 23 September, 2016

Siagian, Sondang P. 2011. Manajemen Sumber Daya Manusia, cetakan Ketujuh. Jakarta: Radar Jaya Offset. Pertama.Yogyakarta: Bagian Penerbitan STIE YKPN.

Suleman Sabir, et all. 2012. Impact of corporate ethical values on ethical leadership and employee performance. International Journal of Business and Social Science Vol. 3 No. 2 [Special Issue - January 2012].

Thushel Jayaweera. 2015. Impact of Work Environmental Factors on Job Performance, Mediating Role of Work Motivation: A Study of Hotel Sector in England. International Journal of Business and Management; Vol. 10, No. 3; 2015 ISSN 1833-3850 E-ISSN 1833-8119 Published by Canadian Center of Science and Education

Treville, et all. 2015. Can Standard Operating Procedures be Motivating? Reconciling Process Variability Issues and Behavioural Outcomes. Total Quality Management Vol. 16, No. 2, 231-241, March 2005

West, Michael. 2012. Kerja Sama yang Efektif, Cetakan Kelima, Penerjemah: Srikandi Waluyo. Yogyakarta: Penerbit Kanisius.

Yukl, Gary. 2011. Leadership in Organization. New Jersey : Prentice-Hall, In 